\title{
Selective transfer of persistent organic pollutants and their metabolites in grey seals during lactation
}

\author{
Marie Vanden Berghe a , Liesbeth Weijs ${ }^{\text {b,c }}$, Sarah Habran ${ }^{d}$, Krishna Das ${ }^{\text {d }}$, Céline Bugli e, Jean-François Rees ${ }^{a}$, \\ Paddy Pomeroy ${ }^{\mathrm{f}}$, Adrian Covaci ${ }^{\mathrm{b}, \mathrm{c}}$, Cathy Debier ${ }^{\mathrm{a}, *}$
}

a Institut des sciences de la vie, Université catholique de Louvain, Croix du Sud 2/L7.05.08, 1343 Louvain-la-Neuve, Belgium

b Toxicological Centre, University of Antwerp, Universiteitsplein 1, 2610 Wilrijk, Belgium

c Ecophysiology, Biochemistry \& Toxicology, University of Antwerp, Groenenborgerlaan 171, 2020 Antwerp, Belgium

' Laboratoire d'Océanologie, Université de Liège, Allée de la Chimie 3, 4000 Liège, Belgium

e Institut de statistique, Université catholique de Louvain, Voie du Roman Pays, 20, 1348 Louvain-la-Neuve, Belgium

${ }^{\mathrm{f}}$ Sea Mammal Research Unit, University of St Andrews, St Andrews, Fife KY16 9AJ, Scotland, United Kingdom

\section{A R T I C L E I N F O}

\section{Article history:}

Received 9 December 2011

Accepted 26 April 2012

Available online 31 May 2012

\section{Keywords:}

Grey seal

Organochlorines

Maternal transfer

Blubber

Milk

Serum

\begin{abstract}
A B S T R A C T
Twenty grey seal (Halichoerus grypus) mother-pup pairs from the colony of the Isle of May (Scotland) were sampled at early and late lactation in order to study the transfer of polychlorinated biphenyls (PCBs), polybrominated diphenyl ethers (PBDEs) and their metabolites (HO-PCBs and HO-PBDEs) as well as organochlorine pesticides (OCPs), such as DDT and metabolites (DDXs) and hexachlorobenzene (HCB). The transfer of the naturally produced MeO-PBDEs was also investigated. Generally, concentrations (on a lipid weight basis) of the sum of PCBs, PBDEs and DDXs tended to be higher in all tissues at late lactation (for maternal outer blubber $\Sigma$ PCBs $=3860 \pm 2091 \mathrm{ng} / \mathrm{g}, \Sigma \mathrm{PBDEs}=120 \pm 74 \mathrm{ng} / \mathrm{g}$ and $\Sigma \mathrm{DDXs}=559 \pm 207 \mathrm{ng} / \mathrm{g}$; for maternal inner blubber $\Sigma$ PCBs $=4229 \pm 3274 \mathrm{ng} / \mathrm{g}, \quad \sum P B D E s=148 \pm 118 \mathrm{ng} / \mathrm{g}$ and $\Sigma$ DDXs $=704 \pm$ $353 \mathrm{ng} / \mathrm{g}$; for maternal serum $\Sigma P C B s=1271 \pm 796 \mathrm{ng} / \mathrm{g}, \quad \Sigma P B D E s=27 \pm 16 \mathrm{ng} / \mathrm{g}$ and $\Sigma$ DDXs $=242 \pm$ $125 \mathrm{ng} / \mathrm{g}$; for milk $\Sigma$ PCBs $=1190 \pm 747 \mathrm{ng} / \mathrm{g}$, $\Sigma$ PBDEs $=55 \pm 36 \mathrm{ng} / \mathrm{g}$ and $\Sigma \mathrm{DDXs}=357 \pm 160 \mathrm{ng} / \mathrm{g}$; for pup serum $\Sigma$ PCBs $=1451 \pm 901 \mathrm{ng} / \mathrm{g}, \quad \Sigma P B D E s=48 \pm 31 \mathrm{ng} / \mathrm{g}$ and $\Sigma \mathrm{DDXs}=395 \pm 201 \mathrm{ng} / \mathrm{g}$ ). In all tissues, $\Sigma \mathrm{MeO}-\mathrm{PBDEs}$ were found at very low levels or even undetected and their concentrations appeared to increase at late lactation only in maternal inner blubber $(2.7 \pm 1.3$ to $5.3 \pm 2.9 \mathrm{ng} / \mathrm{g}$ for early and late lactation, respectively) and milk ( $0.6 \pm 0.3$ to $1.1 \pm 0.5 \mathrm{ng} / \mathrm{g}$ for early and late lactation, respectively). The transfer from inner blubber to maternal serum was selective and strongly depended on the log $K_{o w}$ value of the compounds, with less lipophilic compounds being more efficiently released. Only a limited amount of HO-PCBs was transferred during lactation as 4-HO-CB-107 was the only metabolite detected in milk (29 to $40 \mathrm{pg} / \mathrm{g} \mathrm{lw}$ ). On the contrary, most of HO-PCB metabolites found in maternal serum were also detected in pup serum. These findings suggest not only a transplacental transfer of HO-PCBs from mothers to pups but also the possibility of endogenous biotransformation in suckling pups or accumulation of undetectable low amounts from milk.
\end{abstract}

(c) 2012 Elsevier Ltd. All rights reserved.

\section{Introduction}

Persistent organic pollutants (POPs) such as polychlorinated biphenyls (PCBs), polybrominated diphenyl ethers (PBDEs) and organochlorine pesticides (OCPs) are well known anthropogenic and lipophilic compounds that bioaccumulate throughout the trophic chain. PCB and PBDE metabolites such as hydroxylated PCBs (HO-PCBs)

\footnotetext{
* Corresponding author. Tel.: + 32104737 32; fax: + 3210473728.

E-mail addresses: marie.vandenberghe@uclouvain.be (M. Vanden Berghe), liesbeth.weijs@ua.ac.be (L. Weijs), S.Habran@ulg.ac.be (S. Habran), krishna.das@ulg.ac.be (K. Das), celine.bugli@uclouvain.be (C. Bugli), jf.rees@uclouvain.be (J-F. Rees), pp6@st-andrews.ac.uk (P. Pomeroy), adrian.covaci@ua.ac.be (A.Covaci), cathy.debier@uclouvain.be (C. Debier).
}

and hydroxylated PBDEs (HO-PBDEs) may have comparable or even higher toxic effects than their parent compounds in mammals, especially on thyroid and vitamin A metabolism (Meerts et al., 2000, 2002). Although differences among species exist, it has been suggested that the formation of HO-PCBs results from the metabolic biotransformation of PCBs by cytochrome P450 enzymes (CYPs) in order to make them more water soluble and thus easier to eliminate. However, due to their high affinity for blood proteins (Letcher et al., 2000), specific metabolites were found to be retained in human (Dirtu et al., 2010) and marine mammal blood (Gabrielsen et al., 2011; Weijs et al., 2009c). By contrast, HO-PBDEs can be either biotransformation products of synthetic PBDEs mediated by CYPs or produced by marine organisms such as sponges or algae (Malmvärn et al., 2005; Vetter et al., 2002; Wiseman et al., 2011). They can also result from the demethylation of other naturally- 
produced PBDE analogs, the methoxylated polybrominated diphenyl ethers (MeO-PBDEs), as demonstrated in microsomal fractions of several species of vertebrates (Wan et al., 2009; Wiseman et al., 2011). MeO-PBDEs have already been detected in wildlife and marine mammals at concentrations sometimes greater than PBDEs (Teuten et al., 2005; Wan et al., 2009; Weijs et al., 2009a, 2010).

Because seals are top predators, have a long life span and are characterised by high lipid content (blubber), large concentrations of POPs are found in their tissues, especially in the blubber (Sørmo et al., 2003; Weijs et al., 2009b). When food intake is irregular or nonexistent during breeding, lactation and moulting in most species of seals, important amounts of POPs are mobilised from blubber into the bloodstream, exposing targeted organs to increased concentrations of toxicants (Debier et al., 2006; Vanden Berghe et al., 2010). During lactation, seals produce lipid-rich milk containing high levels of POPs (Debier et al., 2003b; Frouin et al., 2012; Sørmo et al., 2003; Vanden Berghe et al., 2010). Suckling newborns are thus exposed to high amounts of toxic chemicals, while being in a critical developmental period of their life. Previous studies have shown that pup or juvenile seals exposed to POPs, even to low concentrations, had reduced immune competence and impairment of thyroid hormone and vitamin A homeostasis (Hall et al., 2003; Mos et al., 2007; Simms et al., 2000; Sørmo, 2009). The lactational transfer of PCBs and OCPs in seals is more important at late lactation (Debier et al., 2003b). In addition, it appears to be selective, with a preferential transfer of mostly less lipophilic compounds from mother to pup, as shown for grey seals (Halichoerus grypus) (Debier et al., 2003a; Pomeroy et al., 1996; Sørmo et al., 2003). The lactational transfer of PBDEs in marine mammals has been much less investigated. Studies on grey seals and hooded seals (Cystophora cristata) also report a selective transfer of PBDEs during lactation (Ikonomou and Addison, 2008; Wolkers et al., 2006). However, those studies used a limited number of mother-pup pairs (5 to 6) and sampled only once during the lactation period. Therefore, the temporal trend in the transfer could not be established. To the best of our knowledge, only one recent study examined the changes in PBDE concentrations occurring in tissues of mothers and pups harp seal (Phoca groenlandica) sampled twice during the lactation (Frouin et al., 2012). However, as for the previous studies, only a limited number of individuals could be sampled $(n=6)$. In addition, the authors discussed their results for total PBDEs rather than for each single PBDE congener.

The presence and activities of CYPs in several species of seals (Nyman et al., 2001; Wolkers et al., 2002) suggest that they are theoretically able to produce HO-PCBs and HO-PBDEs. Indeed, HOPCBs were detected in significant amounts in adult and pup seals (Gabrielsen et al., 2011; Løken et al., 2008). On the contrary, no or only low levels of HO-PBDEs were found in serum or plasma of harbour (Phoca vitulina) and ringed (Phoca hispida) seals (Routti et al., 2009; Weijs et al., 2009c), suggesting that formation or retention of these molecules is low in these animals. Studies on humans and rodents reported that $\mathrm{HO}-\mathrm{PCBs}$ were transferred to offspring mainly through the placenta during gestation and to a lesser extent during lactation (Fangstrom et al., 2005; Guvenius et al., 2003; Meerts et al., 2002). However, information concerning the maternal transfer of HO-PCBs and HO-PBDEs in marine mammals is lacking. Gabrielsen et al. (2011) found positive correlations between serum HO-PCB levels and the age and body mass of hooded seal pups. The authors suggested thus a transfer of HO-PCBs via the milk or an endogenous biotransformation of PCBs in pups. Nevertheless, that study did not investigate changes occurring during lactation and the presence of HO-PCBs in milk.

The present study investigated the lactational transfer of several POPs in grey seals. Grey seal females fast during a short lactation period (16 to 21 days), while producing milk rich in lipids (up to 60\%) (Iverson et al., 1993; Pomeroy et al., 1996). During that time, females can lose between 25 and $50 \%$ of their initial body mass
(Iverson et al., 1993; Pomeroy et al., 1999). In contrast, due to the important daily ingestion of milk, suckling pups rapidly gain mass (between 0.8 and $2.8 \mathrm{~kg} / \mathrm{day}$ ) (Iverson et al., 1993; Pomeroy et al., 1999). Maternal blubber, maternal serum, milk and pup serum from 20 mother-pup pairs were collected at early and late lactation in order to examine the changes in levels and profiles of PCBs, PBDEs, their related metabolites (HO-PCBs and HO-PBDEs), OCPs and MeOPBDEs between early and late lactation. To the best of our knowledge, this is the first study to investigate the levels and profiles of PBDEs, HO-PCBs, HO-PBDEs and MeO-PBDEs in tissues of grey seal motherpup pairs sampled at different times of the lactation period.

\section{Material and methods}

\subsection{Seal sampling}

Twenty grey seal mother-pup pairs from the Isle of May (IOM), Scotland, were studied during the breeding season in NovemberDecember 2008. On their arrival on the Isle, females were monitored and dates of birth were recorded by daily observations of the breeding areas. Animals were sampled at early (days 2-5) and at late (days 14-17) lactation in order to collect maternal blubber, serum and milk as well as pup serum samples. Pup blubber samples could not be collected due to permit limitation. However, Frouin et al. (2011) reported a strong relationship between $\Sigma$ PBDE levels in blubber and serum of harbour, harp and grey seal pups. The investigators concluded that serum was a reliable indicator for $\Sigma$ PBDE contaminations in seal pups. In addition, another study from the same authors (Frouin et al., 2012) recently measured several POPs in harp seal pup blubber and serum and the concentrations (expressed per unit of lipid weight) reported in both tissues fell within the same ranges. Data concerning pup age as well as body weights of mothers and pups at each capture are presented in Table S1 (supplementary information). Sampling techniques are described elsewhere (Debier et al., 2002, 2003b). Animals were handled and weighed under UK Home Office licence as described in Pomeroy et al. (1996). All the samples were stored at $-20{ }^{\circ} \mathrm{C}$ until analyses.

\subsection{Analysis}

In all samples, 35 PCB congeners (IUPAC numbers: CB-18, $-28,-44$, $-47,-49,-52,-87,-95,-99,-101,-105,-110,-118,-128,-138,-146$, $-149,-151,-153,-156,-158,-170,-171,-172,-174,-177,-180,-183$, $-187,-194,-195,-199,-205,-206$ and -209), 6 PBDEs (IUPAC numbers: BDE-28, $-47,-99,-100,-153$ and -154$), 6$ DDXs (o, $p^{\prime}$-DDD, $o, p^{\prime}$-DDT, o, $p^{\prime}$-DDE, $p, p^{\prime}$-DDD, $p, p^{\prime}-\mathrm{DDE}$, and $p, p^{\prime}$-DDT), HCB and 2 MeO-PBDEs (2'-MeO-BDE-68 and 6-MeO-BDE-47) were targeted. Additionally, twenty HO-PCB congeners were investigated in serum and milk: 3-HO-CB (118, 138, 153, 180), 4-HO-CB (109, 120, 127 , $130,146,162,163,172,177,187,193,198,199,202,208)$ and $4-$ diHO-CB202. Three HO-PBDEs were targeted in all serum and milk samples as well (6-HO-BDE47, 5-HO-BDE47 and 4-HO-BDE49).

The method used for the extraction and clean-up of blubber samples is described in details in Covaci et al. (2008). In brief, approximately $150 \mathrm{mg}$ of each end of the blubber biopsy (outer and inner parts) was homogenised with anhydrous $\mathrm{Na}_{2} \mathrm{SO}_{4}$ and internal standards (CB 143 and BDE 77) were added. The samples were extracted by hot Soxhlet with hexane/acetone $(3 / 1 ; \mathrm{v} / \mathrm{v})$ and the remaining extract was cleaned up on acid silica. After elution of the analytes with $20 \mathrm{ml}$ hexane and $15 \mathrm{ml}$ dichloromethane (DCM), the cleaned extract was evaporated and dissolved in $150 \mu \mathrm{l}$ iso-octane.

Serum samples were analysed as already described in Weijs et al. (2009c) with small adaptations in order to include the analysis of MeO-PBDEs. Briefly, serum (about $1.5 \mathrm{ml}$ ) was spiked with internal standards (CB 143 and BDE 77 for compounds eluting in the 1st fraction, e.g. neutrals; 4'-HO-CB 159 and 3-MeO-BDE28 for compounds eluting 
in the 2nd fraction, e.g. phenolics and MeO-PBDEs), diluted with Milli-Q water, mixed with formic acid and sonicated for $20 \mathrm{~min}$. The samples were extracted on solid-phase-extraction (SPE) cartridges (Oasis HLB, $3 \mathrm{ml} / 200 \mathrm{mg}$ ) and eluted with $\mathrm{MeOH} / \mathrm{DCM}(1 / 1 ; \mathrm{v} / \mathrm{v})$. The extract was evaporated to dryness and reconstituted in $500 \mu \mathrm{l}$ hexane before being fractionated on silica SPE cartridges $(3 \mathrm{ml} / 500 \mathrm{mg})$. The 1 st fraction containing neutral compounds (PCBs, PBDEs and OCPs) was eluted with $6 \mathrm{ml}$ hexane, evaporated to dryness and resolubilised in $100 \mu \mathrm{l}$ isooctane. The 2nd fraction containing the phenolic compounds (HO-PCBs and HO-PBDEs) and MeO-PBDEs, was eluted with $8 \mathrm{ml} \mathrm{DCM}$, evaporated to dryness and derivatised for $30 \mathrm{~min}$ with trimethylsilyldiazomethane to form methyl-derivatives. After solvent evaporation, the dry residue was resolubilised in $75 \mu \mathrm{l}$ iso-octane.

The same extraction method as for blubber was applied to milk samples with minor adaptations. Approximately $400 \mathrm{mg}$ of milk was mixed with anhydrous $\mathrm{Na}_{2} \mathrm{SO}_{4}$ and spiked with internal standards CB143, BDE77 and 4'-HO-CB 159. After extraction by hot Soxhlet and clean-up, the extract was eluted with a $50 \mathrm{ml}$ hexane/DCM mixture $(1 / 1 ; \mathrm{v} / \mathrm{v})$, evaporated and dissolved in $150 \mu \mathrm{l}$ iso-octane. After analysis of the neutral compounds, the extract was further fractionated on silica SPE cartridges, as described above for serum samples. The 2 nd fraction was derivatised, evaporated and resolubilised in $50 \mu$ iso-octane.

Lipid determination for blubber and milk was performed gravimetrically on an aliquot of the extract directly after the Soxhlet extraction. For serum, the different lipid classes (total cholesterol (CHOL), phospholipids (PPL), triacylglycerols (TG) and nonesterified fatty acids (NEFA)) were determined using enzymatic kits from Diasys (Diasys Diagnostics System, Holzheim, Germany) and Wako (Wako Chemicals USA Inc., Richmond, VA). Serum total lipid concentrations were calculated by summing the individual lipid classes. The concentrations of the different lipid classes were calculated on the basis of standard equivalents, as recommended by the respective kits.

Quality assurance and quality control were performed through the analysis of procedural blanks and a standard reference material from the National Institute of Standards and Technology (NIST) (SRM 1945, OCPs, PCBs, and PBDEs in whale blubber). For the SRM 1945, the relative standard deviations (RSD) were $<10 \%$ for most analytes. Additionally, the method performance was assessed through successful participation to interlaboratory studies organised by NIST. Procedural blanks were consistent $(\mathrm{RSD}<20 \%)$ and therefore, the mean value of each analyte in the procedural blanks was used for subtraction. Method quantification limits (LOQs) for individual OCPs, PCB and PBDE congeners were based on procedural blanks (3 times the standard deviation) and the amount of sample taken for analysis.

For OCPs, PCBs and PBDEs in serum, QC was assessed through regular participation to interlaboratory comparison exercises organised by AMAP (POPs in serum). Obtained values were deviating no more than $20 \%$ from the consensus values. For HO-PCBs and MeO-PBDEs, the mean recovery of internal standards $4^{\prime}-\mathrm{HO}-\mathrm{CB} 159$ and 3-MeO-BDE28 in serum was $96 \pm$ $2 \%$ and $94 \pm 5 \%$, respectively. Recoveries of individual HO-PCBs and MeO-PBDEs assessed through spiking experiments at 25 and $125 \mathrm{pg} / \mathrm{ml}$ ranged between 90 and $93 \%$ with good precision ( $\mathrm{RSD}<5 \%$ ).

All compounds were measured with an Agilent 6890 gas chromatograph coupled with a 5973 mass spectrometer system (GC-MS). For the analysis of PBDEs and phenolics, the MS operated in electron capture negative ionisation (ECNI) mode equipped with a $30 \mathrm{~m} \times 0.25 \mathrm{~mm} \times 0.25 \mu \mathrm{m}$ DB-5 capillary column. For the PCB, HCB and DDX analysis, the MS was operated in electron ionisation (EI) mode and was equipped with a $25 \mathrm{~m} \times 0.22 \mathrm{~mm} \times 0.25 \mu \mathrm{m}$ HT8 capillary column. The MS was used in the SIM mode with 2 ions monitored for each PCB homologue group.

\subsection{Partitioning between tissues}

The ratios between maternal blubber and serum as well as between maternal serum and milk were calculated for all POPs, using lipid adjusted measurements. To do so, levels detected in maternal serum were divided by levels detected in maternal inner blubber (partitioning between blubber and serum) and levels found in milk were divided by levels found in maternal serum (partitioning between maternal serum and milk). Values $>1$ indicate a higher preference of the compounds for maternal serum or milk compared to maternal inner blubber or maternal serum, respectively. These ratios were calculated only for late lactation as this is the stage of lactation with the highest POP transfer (Debier et al., 2003b; Sørmo et al., 2003; Vanden Berghe et al., 2010).

\subsection{Statistical analyses}

Statistical analyses were conducted using SPSS 17 for Windows. Contaminant levels were LN-transformed to normalise the data and to reduce inter-individual variability. For concentrations below the limit of quantification (LOQ), a value of LOQ*detection frequency ( $f$ ) for each tissue was used. Linear mixed models (LMMs) were used to test differences in contaminant concentrations and profiles between both lactation periods within the same tissue. The individual was considered as a random explanatory variable, while the lactation period (early and late) was determined as a fixed variable. When possible, the transfer of contaminants between tissues (maternal blubber $\rightarrow$ maternal serum $\rightarrow$ milk $\rightarrow$ pup serum) was investigated by adding the concentrations found in the "previous" tissue in the pre-cited model (e.g., PCB levels found in maternal inner blubber were used as a fixed variable in order to explain PCB levels in maternal serum). The level of statistical significance was set at $\mathrm{p} \leq 0.05$ for all analyses. Results concerning the LMMs of the profiles can be found in the Table S3 of the supplementary information.

\section{Results}

3.1. Lipids

The lipid percentage of maternal inner and outer layers decreased significantly between early and late lactation (Table 1). In maternal serum samples, the PPL fraction was the most important for both periods, representing about $60 \%$ of the total lipid content (Table S2). The total lipid content in maternal serum decreased significantly between early and late lactation (Table 1). On the other hand, the lipid percentage in milk (hexane/acetone-extractable fat) significantly increased at late lactation (Table 1). Similar to maternal serum, the dominant lipid class in pup serum was PPL, representing about $45 \%$ of the total lipid content (Table S2). The total lipid content in pup serum increased significantly between early and late lactation (Table 1). Changes in PCB, PBDE, OCP and MeO-PBDE levels between early and late lactation in all tissues were discussed on a lipid weight basis. However, since HO-PCBs and HO-PBDEs have also a high affinity for other serum constituents than lipids, such as blood proteins, changes in hydroxylated metabolite levels between both lactation periods in serum were examined on a wet weight basis.

\section{2. $P C B S$}

PCB concentrations were the highest of all POPs measured in the investigated tissues (Table 1). In all tissues and for both periods, CB-153 was the predominant $\mathrm{PCB}$ congener followed by $\mathrm{CB}-138$ or $\mathrm{CB}-180$. Together, these three $\mathrm{PCB}$ congeners accounted for more than $55 \%$ of the total PCBs. CB-99, $-101,-118,-128,-146,-149$, $-170,-183$ and -187 were also systematically found in all samples but their contribution varied with the tissue and the period. The detection frequency of the different congeners in a given tissue can be found in Table S4a of the supplementary information.

The statistical treatments were performed on congener groups according to their degree of chlorination, namely tri-CBs (CB-18 and -28), tetra-CBs (CB-44, -47, -49 and -52 ), penta-CBs (CB-87, $-95,-99,-101,-105,-110$ and -118$)$, hexa-CBs (CB-128, $-132,-146,-149,-151,-153$ and -156$)$, hepta-CBs (CB-170, -171, -172, -174, -177, $-180,-183$ and -187$)$, octa-CBs (CB-194, $-195,-199$ and -205$)$ and nona/deca-CBs (CB-206 and -209). Because tri-CBs were only detected at very low concentrations in a limited number of samples in all investigated tissues, statistical analyses were not carried out for this group.

\subsubsection{Variations in concentrations}

Significantly higher concentrations were found at late lactation in maternal outer and inner blubber for $\mathrm{Z}$ PCBs and this observation was true for all PCB groups ( $\mathrm{p}$-values between $<0.001$ and 0.009 ) (Table 1 ). In maternal serum, we observed an increase in 
Table 1

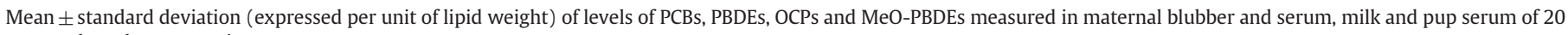
grey seal mother-pup pairs.

\begin{tabular}{|c|c|c|c|c|c|c|c|c|c|c|}
\hline & \multicolumn{2}{|c|}{ Outer blubber (ng/g) ${ }^{\mathrm{a}}$} & \multicolumn{2}{|c|}{ Inner blubber $(\mathrm{ng} / \mathrm{g})^{\mathrm{a}}$} & \multicolumn{2}{|c|}{ Maternal serum $(\mathrm{ng} / \mathrm{g})^{\mathrm{a}}$} & \multicolumn{2}{|l|}{$\operatorname{Milk}(\mathrm{ng} / \mathrm{g})^{\mathrm{a}}$} & \multicolumn{2}{|c|}{ Pup serum $(n g / g)^{a}$} \\
\hline & $\begin{array}{l}\text { Early } \\
\text { lactation }\end{array}$ & $\begin{array}{l}\text { Late } \\
\text { lactation }\end{array}$ & $\begin{array}{l}\text { Early } \\
\text { lactation }\end{array}$ & $\begin{array}{l}\text { Late } \\
\text { lactation }\end{array}$ & $\begin{array}{l}\text { Early } \\
\text { lactation }\end{array}$ & $\begin{array}{l}\text { Late } \\
\text { lactation }\end{array}$ & $\begin{array}{l}\text { Early } \\
\text { lactation }\end{array}$ & $\begin{array}{l}\text { Late } \\
\text { lactation }\end{array}$ & $\begin{array}{l}\text { Early } \\
\text { lactation }\end{array}$ & $\begin{array}{l}\text { Late } \\
\text { lactation }\end{array}$ \\
\hline Lipid content (\%) & $86.7 \pm 3.8$ & $77.5 \pm 8.8^{f}$ & $84.6 \pm 5.0$ & $66.9 \pm 12.9^{f}$ & $0.8 \pm 0.1$ & $0.6 \pm 0.1^{£}$ & $44.9 \pm 6.0$ & $57.5 \pm 5.2^{\S}$ & $0.9 \pm 0.2$ & $1.2 \pm 0.2^{\S}$ \\
\hline$\Sigma$ tri-CBs & $1 \pm 0$ & $7 \pm 12$ & $1 \pm 0$ & $4 \pm 7$ & N.D & N.D & N.D & N.D & $2 \pm 1$ & $5 \pm 1$ \\
\hline Etetra-CBs & $17 \pm 6$ & $21 \pm 11 \S$ & $15 \pm 4$ & $27 \pm 16^{\S}$ & $14 \pm 5$ & $19 \pm 6$ & $17 \pm 5$ & $20 \pm 7$ & $23 \pm 9$ & $34 \pm 13^{\S}$ \\
\hline ¿penta-CBs & $146 \pm 61$ & $179 \pm 76^{\S}$ & $116 \pm 40$ & $260 \pm 146^{\S}$ & $65 \pm 2$ & $103 \pm 45^{\S}$ & $83 \pm 27$ & $118 \pm 52$ & $115 \pm 49$ & $182 \pm 84^{\S}$ \\
\hline ¿hexa-CBs & $1431 \pm 895$ & $1913 \pm 1010^{\S}$ & $850 \pm 435$ & $2292 \pm 1709^{\S}$ & $350 \pm 136$ & $770 \pm 476$ & $416 \pm 151$ & $726 \pm 469$ & $585 \pm 269$ & $865 \pm 551^{\S}$ \\
\hline ¿hepta-CBs & $928 \pm 705$ & $1301 \pm 802^{\S}$ & $446 \pm 360$ & $1285 \pm 1092^{\S}$ & $114 \pm 51$ & $329 \pm 235^{\S}$ & $134 \pm 53$ & $280 \pm 206$ & $199 \pm 102$ & $309 \pm 227^{\S}$ \\
\hline Locta-CBs & $230 \pm 198$ & $326 \pm 221^{\S}$ & $87 \pm 94$ & $265 \pm 258^{\S}$ & $12 \pm 10$ & $43 \pm 42$ & $34 \pm 14$ & $41 \pm 32$ & $29 \pm 18$ & $47 \pm 40^{\S}$ \\
\hline ¿nona/deca-CBs & $79 \pm 73$ & $114 \pm 82^{\S}$ & $28 \pm 38$ & $97 \pm 106^{\S}$ & $2 \pm 2$ & $8 \pm 12$ & $4 \pm 2$ & $6 \pm 6$ & $5 \pm 5$ & $9 \pm 9^{\S}$ \\
\hline$\Sigma$ PCBs & $2832 \pm 1870$ & $3860 \pm 2091^{\S}$ & $1543 \pm 922$ & $4229 \pm 3274^{\S}$ & $556 \pm 210$ & $1271 \pm 796$ & $688 \pm 234$ & $1190 \pm 747$ & $958 \pm 431$ & $1451 \pm 901^{\S}$ \\
\hline BDE 28 & $0.4 \pm 0.2$ & $0.5 \pm 0.2^{\S}$ & $0.4 \pm 0.2$ & $0.7 \pm 0.4^{\S}$ & N.D & N.D & $0.2 \pm 0.1$ & $0.3 \pm 0.2^{\S}$ & $0.3 \pm 0.2$ & $0.3 \pm 0.2$ \\
\hline BDE 47 & $52.5 \pm 30.2$ & $64.4 \pm 37.8^{\S}$ & $40.5 \pm 21.5$ & $87.3 \pm 60.7^{\S}$ & $10.8 \pm 5.5$ & $18.8 \pm 11.2$ & $23.8 \pm 12.6$ & $42.7 \pm 27.1$ & $27.7 \pm 13.8$ & $38.2 \pm 23.8^{\S}$ \\
\hline BDE 99 & $5.8 \pm 3.3$ & $8.5 \pm 6.6^{\S}$ & $4.7 \pm 4.6$ & $12.8 \pm 14.0^{\S}$ & $0.7 \pm 0.4$ & $1.9 \pm 1.7$ & $1.3 \pm 0.9$ & $3.0 \pm 3.1$ & $3.3 \pm 8.3$ & $2.2 \pm 2.1$ \\
\hline BDE 100 & $12.8 \pm 10.2$ & $16.9 \pm 11.2^{\S}$ & $7.9 \pm 6.1$ & $21.7 \pm 19.9^{\S}$ & $1.1 \pm 0.6$ & $3.2 \pm 2.2^{\S}$ & $2.5 \pm 1.2$ & $5.6 \pm 4.2$ & $2.8 \pm 1.4$ & $4.1 \pm 2.9$ \\
\hline BDE 153 & $12.2 \pm 11.2$ & $17.6 \pm 12.6^{\S}$ & $5.2 \pm 7.0$ & $13.0 \pm 13.5^{\S}$ & $0.4 \pm 0.3$ & $1.3 \pm 1.0^{\S}$ & $0.8 \pm 0.5$ & $1.7 \pm 1.5$ & $1.4 \pm 0.6$ & $1.8 \pm 1.2$ \\
\hline BDE 154 & $8.7 \pm 11.5$ & $11.8 \pm 12.8^{\S}$ & $4.5 \pm 5.2$ & $11.6 \pm 13.2^{\S}$ & $0.3 \pm 0.2$ & $1.3 \pm 1.0^{\S}$ & $0.7 \pm 0.5$ & $1.6 \pm 1.7$ & $1.0 \pm 0.9$ & $1.3 \pm 1.7$ \\
\hline$\Sigma$ PBDEs & $93.0 \pm 62.5$ & $120.3 \pm 74.2^{\S}$ & $63.6 \pm 44.8$ & $148.1 \pm 117.7^{\S}$ & $13.4 \pm 7.0$ & $26.5 \pm 16.0$ & $29.4 \pm 15.1$ & $54.9 \pm 36.3$ & $36.4 \pm 16.3$ & $48.0 \pm 30.5$ \\
\hline$p, p^{\prime}-\mathrm{DDD}$ & $5 \pm 3$ & $6 \pm 4$ & $6 \pm 3$ & $10 \pm 7^{\S}$ & $2 \pm 2$ & $3 \pm 3^{\S}$ & $7 \pm 3$ & $9 \pm 3^{\S}$ & $<1$ & $1 \pm 2$ \\
\hline$p, p^{\prime}-\mathrm{DDE}$ & $413 \pm 184$ & $509 \pm 190^{\S}$ & $294 \pm 96$ & $637 \pm 316^{\S}$ & $147 \pm 50$ & $218 \pm 111^{\S}$ & $203 \pm 70$ & $313 \pm 138^{\S}$ & $259 \pm 113$ & $373 \pm 186^{\S}$ \\
\hline$p, p^{\prime}-\mathrm{DDT}$ & $34 \pm 24$ & $44 \pm 25^{\S}$ & $24 \pm 15$ & $57 \pm 42^{\S}$ & $14 \pm 5$ & $20 \pm 14$ & $21 \pm 8$ & $35 \pm 21^{\S}$ & $17 \pm 9$ & $21 \pm 14$ \\
\hline$\Sigma$, DDXs & $452 \pm 201$ & $559 \pm 207^{\S}$ & $323 \pm 106$ & $704 \pm 353^{\S}$ & $162 \pm 55$ & $242 \pm 125$ & $230 \pm 78$ & $357 \pm 160^{\S}$ & $276 \pm 120$ & $395 \pm 201^{\S}$ \\
\hline HCB & $7 \pm 8$ & $\mathbf{9} \pm \overline{\mathbf{1 1}}^{\S}$ & $7 \pm 8$ & $11 \pm 13$ & $7 \pm 8$ & $7 \pm \overline{10}$ & $11 \pm 10$ & $12 \pm 13$ & $16 \pm 23$ & $17 \pm 20$ \\
\hline 6-MeO-BDE47 & $2.3 \pm 0.0$ & $2.4 \pm 1.2$ & $2.2 \pm 1.1$ & $4.2 \pm 2.3^{\S}$ & $0.4 \pm 0.2$ & $0.6 \pm 0.3$ & $0.5 \pm 0.2$ & $0.9 \pm 0.5^{\S}$ & N.D & N.D \\
\hline 2'-MeO-BDE68 & $0.6 \pm 0.3$ & $0.6 \pm 0.3$ & $0.6 \pm 0.3$ & $1.2 \pm 0.7^{\S}$ & N.D & N.D & $0.1 \pm 0.0$ & $0.2 \pm 0.1^{\S}$ & N.D & N.D \\
\hline ¿MeO-PBDEs & $2.9 \pm 1.1$ & $3.1 \pm 1.4$ & $2.7 \pm 1.3$ & $5.3 \pm 2.9^{\S}$ & $0.4 \pm 0.2$ & $0.6 \pm 0.3$ & $0.6 \pm 0.3$ & $1.1 \pm 0.5^{\S}$ & N.D & N.D \\
\hline
\end{tabular}

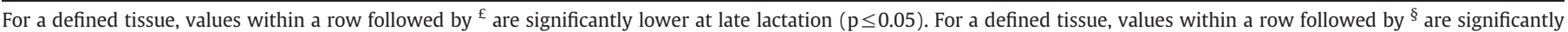
higher at late lactation $(\mathrm{p} \leq 0.05)$. N.D = not detected; $\mathrm{N} . \mathrm{M}=$ not measured.

a Statistics were performed on LN transformed values.

all PCB groups and thus $\mathrm{ZPCB}$ at late lactation (Table 1). However, this increase appeared to be significant only for the penta- and hepta-CBs $\left(\mathrm{p}_{5-\mathrm{Cl}}<0.011\right.$ and $\mathrm{p}_{7-\mathrm{Cl}}=0.019$ ) (Table 1). In milk, although concentrations of $\mathrm{ZPCBs}$ and all PCB groups tended to be higher at late lactation, no significant change could be found (Table 1). In serum of suckling pups, all PCB groups as well as $\Sigma$ PCBs increased significantly between early and late lactation ( $p$-values between $<0.001$ and 0.004 ) (Table 1). In addition to some period effects, our LMMs indicated significant and positive relationships between $\Sigma$ PCBs in maternal outer blubber and maternal inner blubber, $\Sigma$ PCBs in maternal inner blubber and maternal serum and $\mathrm{XPCBs}$ in maternal serum and milk ( $\mathrm{p}$-values between $<0.001$ and 0.028 ).

\subsubsection{Variations in profiles}

The percentages of tetra- to hexa-CBs in maternal outer blubber decreased significantly at late lactation (p-values between 0.009 and 0.011 ), while they increased significantly for hepta- to nona/deca-CBs (p-values between 0.012 and 0.015) (Fig. 1a and Table S3 in the supplementary information). In inner blubber, the proportions of tetra- and penta-CBs declined significantly at late lactation $\left(\mathrm{p}_{4-\mathrm{Cl}}<0.001\right.$ and $\left.\mathrm{p}_{5-\mathrm{Cl}}=0.002\right)$, while the ratios of hepta-CBs increased significantly $(\mathrm{p}=0.019)$ (Fig. 1a and Table S3). The percentages of hexa-, octa- and nona/deca-CBs remained stable. In maternal serum, the percentages of tetra- to hexa-CBs decreased significantly between early and late lactation $(\mathrm{p} \leq 0.001$ for all), while the proportions of hepta- and octa-CBs increased significantly $\left(\mathrm{p}_{7-\mathrm{Cl}}<0.001\right.$ and $\mathrm{p}_{8-\mathrm{Cl}}=0.002$ ). No significant change was observed for nona/deca-CBs (Fig. 1a and Table S3). In milk, the proportions of tetra-, penta-, octa- and nona/deca-CBs decreased significantly at late lactation ( $p$-values between $<0.001$ and 0.013 ), while the ratios of heptaCBs increased significantly $(\mathrm{p}=0.047)$ and the percentages of hexa-CBs remained stable (Fig. 1a and Table S3). In pup serum, no significant changes between early and late lactation were observed in the proportions of all PCB groups (Fig. 1a and Table S3).

\subsection{PBDEs}

BDE-47 was the most dominant congener in all samples representing between $50 \%$ and $80 \%$ of the total PBDEs depending on the tissue. Other important congeners were BDE-99, BDE-100 or BDE-153 depending on the period and the tissue considered. The detection frequency of various congeners in each tissue is summarised in Table S4b of the supplementary information.

\subsubsection{Variations in concentrations}

In maternal outer and inner blubber, $\Sigma$ PBDEs as well as all PBDE congeners increased significantly at late lactation ( $p$-values between $<0.001$ and 0.005 ) (Table 1). In maternal serum, although levels of $\angle$ PBDEs and individual PBDE congeners tended to be higher at late lactation, significant differences were found only for BDE-100, BDE-153 and BDE-154 (p-values between <0.001 and 0.011). In milk, concentrations of $\Sigma$ PBDEs and individual PBDE congeners tended also to be higher at late lactation but no significant change was observed (Table 1). Similarly, no significant change between early and late lactation was found in pup serum (Table 1). The LMMs highlighted significant and positive relationships between LPBDEs in maternal outer blubber and maternal inner blubber, $\Sigma$ PBDEs in maternal inner blubber and maternal serum and $\Sigma$ PBDEs in maternal serum and milk ( $\mathrm{p}$-values $\leq 0.001$ for all).

\subsubsection{Variations in profiles}

The proportions of BDE-47 decreased significantly at late lactation in maternal outer blubber ( $\mathrm{p}=0.014$ ), while the percentages of BDE-100, BDE-153 and BDE-154 increased significantly (p-values between 0.018 and 0.023 ) and those of BDE-28 and BDE-99 remained the same (Fig. 1b and Table S3). In maternal inner blubber, the percentages of BDE-28 and BDE-47 decreased significantly at late lactation $\left(\mathrm{p}_{\mathrm{BDE}-28}=0.003\right.$ and $\mathrm{p}_{\mathrm{BDE}-47}=$ 0.032), while proportions of BDE-99 and BDE-100 increased significantly ( $\mathrm{p}_{\mathrm{BDE}-99}=0.013$ and $\mathrm{p}_{\mathrm{BDE}-100}=0.001$ ) and those of BDE-153 and BDE-154 remained unchanged (Fig. 1b and Table S3). In maternal serum, the percentages of BDE-47 were significantly lower at late lactation $(\mathrm{p}<0.001)$, while those of other congeners increased significantly ( $p$-values between 0.001 and 0.007 ) (Fig. 1b and Table S3). In milk, proportions of BDE-28 decreased significantly $(p=0.004)$, while those of BDE-100 increased significantly $(p=0.019)$ and those of other congeners remained unchanged between early and late lactation (Fig. 1b and Table S3). In pup serum, the percentages of BDE-28 dropped significantly at late lactation, while proportions of other congeners remained stable $(p=0.043)$ (Fig. 1b and Table S3).

\subsection{HO-PCBs and HO-PBDEs}

Because of the larger affinity of hydroxylated metabolites for blood proteins compared to blubber lipids (Letcher et al., 2000), HO-PCBs and HO-PBDEs were not targeted in maternal blubber. Their presence was, however, investigated in milk in order to elucidate a possible lactational transfer pathway to pups. No HO-PBDEs were found in either milk or maternal and pup serum samples.

Among the 20 HO-PCBs targeted in maternal serum, milk and pup serum, 4-HO-CB107 was the most abundant metabolite, representing between 66 and $100 \%$ of the total HO-PCB concentrations. In particular, 4-HO-CB-107 was the only HO metabolite found in milk at very low levels (Table 2). Details on the detection frequency of each metabolite in various tissues can be found in Table S4c.

\subsubsection{Variations in concentrations}

$\Sigma$ HO-PCBs in maternal serum increased significantly at late lactation $(\mathrm{p}=0.002)$ (Table 2). Among all the detected metabolites, only levels of 3-HO-CB-138 and 4-HO-CB107 appeared to increase significantly $\left(\mathrm{p}_{3 \mathrm{HOCB} 138}=0.032\right.$ and $\mathrm{p}_{4 \mathrm{HOCB107}}<0.001$ ). In milk, concentration of 4-HO-CB-107 increased significantly at late lactation $(\mathrm{p}=0.022)$ (Table 2). In pup serum, $\mathbf{L}$ HO-PCBs increased significantly at late lactation and this increase 

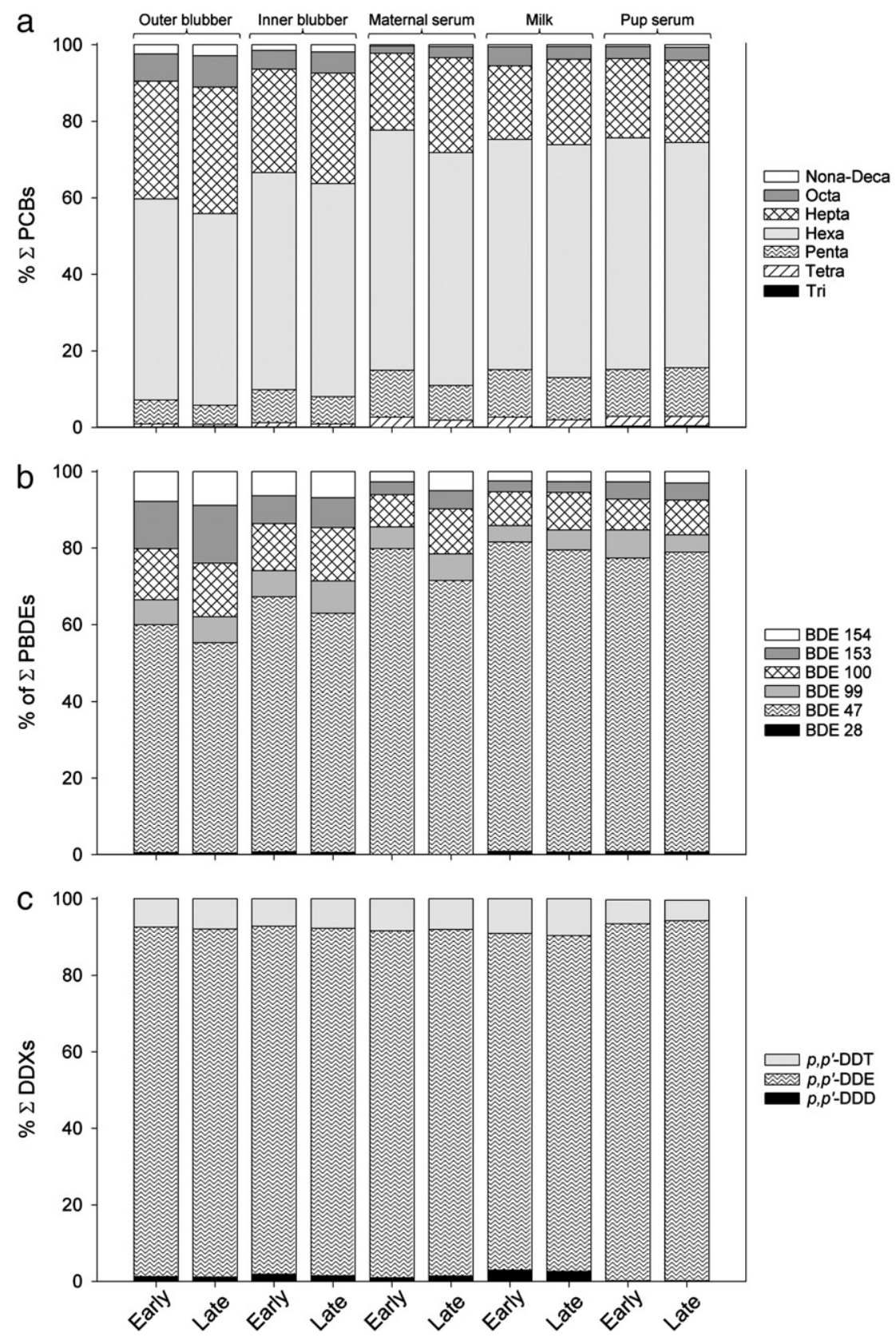

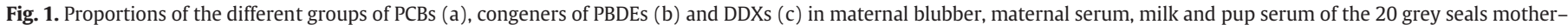
pup pairs.

was observed for all the detected metabolites ( $\mathrm{p}$-values $\leq 0.001$ for all), except for 4 -HO-CB187 (Table 2). No relationships between a defined tissue and the "previous" one could be observed.

\subsubsection{Variations in profiles \\ In maternal serum, only the proportions of 4-HO-CB-162 decreased significantly at late lactation ( $p=0.002$ ) (Fig. 2 and Table S3). In pup serum, a significant increase in the ratios of 4-HO-CB-107 was observed at late lactation ( $p<0.001$ ), while the percentages of 3-HO- CB-138, 4-HO-CB-146 and 4-HO-CB-162 decreased significantly (p-values between $<0.001$ and 0.038 ) (Fig. 2 and Table S3). Proportions of 4-HO-CB-120 and 4-HO-CB-187 remained unchanged.}

\subsection{Pesticides}

For DDXs, the most prevalent metabolite was $p, p^{\prime}$-DDE which contributed for up to $94 \%$ of the total DDXs. $p, p^{\prime}$-DDT represented more than $5 \%$ of the total DDXs. The detection frequency of each compound in a given tissue is presented in Table S4d.

\subsubsection{Variations in concentration}

¿DDXs increased significantly at late lactation in maternal outer blubber $(\mathrm{p}<0.001)$ and this increase was also observed for $p, p^{\prime}$-DDE and $p, p^{\prime}$-DDT levels $(p-$ values $<0.001$ for both) (Table 1$)$. Similarly, HCB levels were also higher at late lactation $(p=0.018)$ (Table 1$)$. In inner blubber, concentrations of the 3 detected DDX metabolites and thus ¿DDXs increased significantly at late lactation (p-values between $<0.001$ and 0.002 ), while HCB levels remained unchanged (Table 1). In maternal serum, no difference between early and late lactation was observed for $\Sigma$ DDXs but $p, p^{\prime}-\mathrm{DDE}$ and $p, p^{\prime}$-DDD increased significantly at late lactation ( $\mathrm{p}_{\mathrm{DDE}}=$ 0.020 and $\mathrm{p}_{\mathrm{DDD}}=0.016$ ) (Table 1 ). HCB levels remained stable (Table 1 ). In milk, ¿DDXs increased significantly at late lactation $(\mathrm{p}=0.001)$ and this increase was seen for the 3 DDX compounds ( $p$-values between 0.001 and 0.013 ) (Table 1). By contrast $\mathrm{HCB}$ concentrations remained stable (Table 1 ). In pup serum, a significant increase was

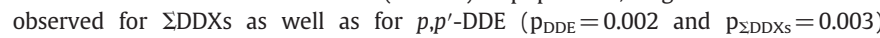
(Table 1). HCB levels remained stable (Table 1). Our LMMs indicated significant and positive relationships between $\mathrm{HCB}$ levels in maternal outer blubber and maternal inner blubber, HCB levels in maternal inner blubber and maternal serum, HCB levels in maternal serum and milk and HCB levels in milk and in pup serum (p-values 
between $<0.001$ and 0.010 ). Regarding LDDXs, positive relationships were found only between levels in maternal outer blubber and maternal inner blubber $(\mathrm{p}<0.001)$

\subsubsection{Variations in DDX profiles}

In maternal outer and inner blubber, only the percentages of $p, p^{\prime}$-DDT increased significantly at late lactation $(p=0.033$ and $p=0.036$ for outer and inner blubber respectively) (Fig. 1c and Table S3). In maternal serum, the percentages of the different isomers remained stable between early and late lactation (Fig. 1c and Table S3). A significant decrease in $p, p^{\prime}$-DDD proportions was observed at late lactation in milk $(\mathrm{p}=0.024)$, while the ratios of $p, p^{\prime}$-DDE and $p, p^{\prime}$-DDT remained stable (Fig. 1c and Table S3). Finally, in pup serum, proportions of $p, p^{\prime}$-DDE increased significantly at late lactation $(\mathrm{p}=0.012)$, while those of $p, p^{\prime}$-DDT decreased significantly $(\mathrm{p}=0.002)$ (Fig. 1c and Table S3).

\section{6. $\mathrm{MeO}-\mathrm{PBDES}$}

Two naturally-produced MeO-PBDEs, 2'-MeO-BDE-68 and 6-MeO-BDE-47, were detected in very low concentrations in maternal blubber and milk with a predominance of 6-MeO-BDE-47 (up to $90 \%$ of total MeO-PBDEs) (Table 1). In maternal serum, only $6-\mathrm{MeO}-\mathrm{BDE}-47$ could be detected in $44 \%$ of the samples. None of the 2 congeners were found in pup serum

\subsubsection{Variations in concentration}

¿MeO-PBDEs increased significantly in maternal inner blubber $(\mathrm{p}<0.001)$ but not in outer blubber. This increase was observed for both congeners ( $\mathrm{p}$-values $<0.001 \mathrm{for}$ both) (Table 1). In maternal serum, concentrations of 6-MeO-BDE-47 did not change between early and late lactation (Table 1). In milk, ¿MeO-PBDEs increased significantly at late lactation and this increase was noticed for both congeners ( $\mathrm{p}$-values between 0.001 and 0.050 ) (Table 1 ). The only significant relationship found in our LMMs was the positive one between $\mathrm{MMeO}$-PBDEs in maternal outer blubber and $\mathrm{\Sigma MeO}$-PBDEs in maternal inner blubber $(\mathrm{p}<0.001)$.

\subsubsection{Variations in profiles}

The percentages of both congeners remained constant between early and late lactation in each tissue (Table S3).

\subsection{Transfer ratios}

Decreasing ratios from maternal inner blubber to maternal serum with the number of chlorine and bromine atoms were observed for the different PCB homologue groups and PBDE congeners (Fig. 3a). In addition, a significant inverse relationship was observed between transfer ratios of PCBs, PBDEs and OCPs and their respective log $\mathrm{K}_{\mathrm{ow}}$ values $\left(\mathrm{R}^{2}=0.810 ; \mathrm{p}<0.001\right.$ ) (Fig. 3a). By contrast, no clear relationship could be observed between POP transfer ratios from maternal serum to milk and their respective $\log \mathrm{K}_{\mathrm{ow}}$ values $\left(R^{2}=0.126 ; p=0.194\right)$ (Fig. 3b).

\section{Discussion}

\subsection{General levels and profiles}

The PCB profiles were dominated by hexa- and hepta-CBs, mainly CB-153, CB-138 and CB-180. Not surprisingly, BDE-47 represented the major PBDE congener and $p, p^{\prime}$-DDE the dominant DDX metabolite. Similar profiles are usually reported in seal species around the world (Espeland et al., 1997; Miranda Filho et al., 2009; Sørmo et al., 2003; Wolkers et al., 2006). ¿PCBs found in maternal blubber in the present study were comparable to those reported for the same grey seal colony sampled 10 and 2 years earlier, respectively (Debier et al., 2003b; Vanden Berghe et al., 2010). Such a similar

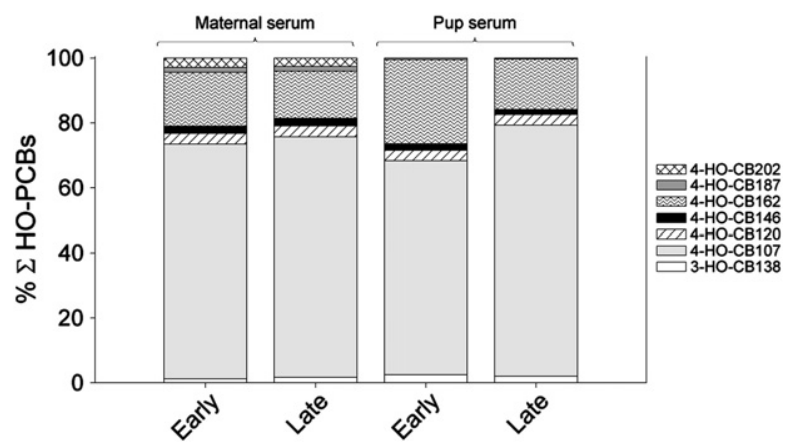

Fig. 2. Proportions of the different metabolites of HO-PCBs in maternal and pup sera of the 20 grey seals mother-pup pairs.

degree of contamination indicates that, although they have been banned for several decades, these contaminants are still present in significant amounts in the northern UK environment and bioaccumulate in organisms. Law et al. (2010) observed an increase of PCBs in the blubber of Scottish harbour porpoises (Phocoena phocoena) between 1995 and 2005 and suggested an atmospheric transport from more contaminated adjacent UK regions. $\Sigma$ PBDEs in maternal blubber were similar to those reported for lactating Canadian grey seal females from Sable Island sampled in 1995 (Ikonomou and Addison, 2008), but 2 to 3 times higher than those found in lactating Canadian harp seal females from Magdalen Islands sampled in 2008 (Frouin et al., 2012). ¿DDXs found in maternal blubber of the present work were much lower than concentrations measured in blubber of lactating grey seal from Canada sampled in 1995 (Sørmo et al., 2003), but similar than those detected in the lactating harp seal females from Magdalen Islands (Frouin et al., 2012). Finally, HCB levels found in the studies of Sørmo et al. (2003) and Frouin et al. (2012) were 2 to 3 times higher than those measured in the present study.

4-HO-CB-107 followed by 4-HO-CB-162 was the prevalent metabolite in maternal and pup sera, which agrees with profiles reported for seals in other studies (Gabrielsen et al., 2011; Løken et al., 2008; Weijs et al., 2009c). 2 HO-PCBs measured in the present study in maternal and pup sera were lower than those found in the blood of hooded seal mother-pup pairs (Gabrielsen et al., 2011) and in other non-lactating phocid seals (Løken et al., 2008; Weijs et al., 2009c). The only data existing about HO-PCBs in milk concern human breast milk. Similar to our grey seal milk, Guvenius et al. (2003) found a predominance of 4-HO-CB-107 in mothers' milk from Sweden, while 4-HO-CB-187 was the prevalent metabolite in human milk from Canada and the Faroe Islands (Fangstrom et al., 2005; Newsome and Davies, 1996). Levels detected in grey seal milk were generally comparable or higher than those detected in human

Table 2

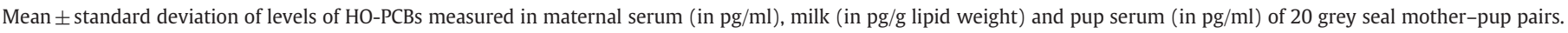

\begin{tabular}{|c|c|c|c|c|c|c|}
\hline \multirow[t]{2}{*}{$\mathrm{HO}-\mathrm{PCBs}$} & \multicolumn{2}{|c|}{ Maternal serum $(\mathrm{pg} / \mathrm{ml})^{\mathrm{a}}$} & \multicolumn{2}{|c|}{ Milk (pg/g lipid weight) ${ }^{\mathrm{a}}$} & \multicolumn{2}{|c|}{ Pup serum $(\mathrm{pg} / \mathrm{ml})^{\mathrm{a}}$} \\
\hline & Early lactation & Late lactation & Early lactation & Late lactation & Early lactation & Late lactation \\
\hline 3-HO-CB138 & $6 \pm 5$ & $11 \pm 10^{\S}$ & N.D & N.D & $10 \pm 6$ & $21 \pm 10^{\S}$ \\
\hline 4-HO-CB107 & $408 \pm 210$ & $486 \pm 250^{\S}$ & $29 \pm 10$ & $40 \pm 17^{\S}$ & $335 \pm 286$ & $827 \pm 355^{\S}$ \\
\hline 4-HO-СB120 & $19 \pm 10$ & $22 \pm 12$ & N.D & N.D & $14 \pm 10$ & $35 \pm 15^{\S}$ \\
\hline 4-HO-CB146 & $12 \pm 7$ & $16 \pm 9$ & N.D & N.D & $9 \pm 7$ & $18 \pm 11^{\S}$ \\
\hline 4-HO-CB162 & $93 \pm 51$ & $94 \pm 53$ & N.D & N.D & $130 \pm 116$ & $173 \pm 107^{\S}$ \\
\hline 4-HO-CB187 & $7 \pm 6$ & $9 \pm 6$ & N.D & N.D & $3 \pm 4$ & $3 \pm 5$ \\
\hline 4-HO-СB202 & $14 \pm 8$ & $16 \pm 10$ & N.D & N.D & N.D & N.D \\
\hline$\Sigma$ HO-PCBS & $558 \pm 271$ & $654 \pm 329^{\S}$ & $29 \pm 10$ & $40 \pm 17^{\S}$ & $501 \pm 421$ & $1077 \pm 484^{\S}$ \\
\hline
\end{tabular}

For a defined tissue, values within a row followed by ${ }^{\S}$ are significantly higher at late lactation $(\mathrm{p} \leq 0.05)$. N.D $=$ not detected.

a Statistics were performed on LN transformed values. 
milk (Guvenius et al., 2003; Newsome and Davies, 1996), except for the Faroese population which is exposed to important levels of POPs due to their consumption of pilot whale meat and blubber (Fangstrom et al., 2005).

None of the investigated HO-PBDEs could be detected in either serum or milk. This result corroborates previous findings that reported no or only low concentrations of circulating HO-PBDEs in harbour and ringed seals (Routti et al., 2009; Weijs et al., 2009c). The authors suggested that biotransformation of PBDEs or retention of HO-PBDEs was low in those species. Additionally, it has been suggested that the primary source of HO-PBDEs may originate from the demethylation of naturally-produced MeO-PBDEs (Wan et al., 2009). In the present study, MeO-PBDEs were absent or found at very low concentrations in all tissues. 6-MeO-BDE47 was the predominant congener. This is in agreement with previous studies reporting that $6-\mathrm{MeO}-\mathrm{BDE} 47$ was the main congener found in marine mammals from the Northern hemisphere (Covaci et al., 2010; Weijs et al., 2009a). Levels of MeO-PBDEs in grey seals of the present study were relatively low compared to those found in blubber of harbour seal females from the North Sea (Weijs et al., 2009a).

\subsection{Maternal transfer of PCBs, PBDEs and OCPS}

\subsubsection{Variations in concentrations}

The blubber of marine mammals is composed primarily of fatty acids stored as triacylglycerols (Wheatley et al., 2008). Earlier studies reported that fatty acid mobilisation during fasting in seals occurred
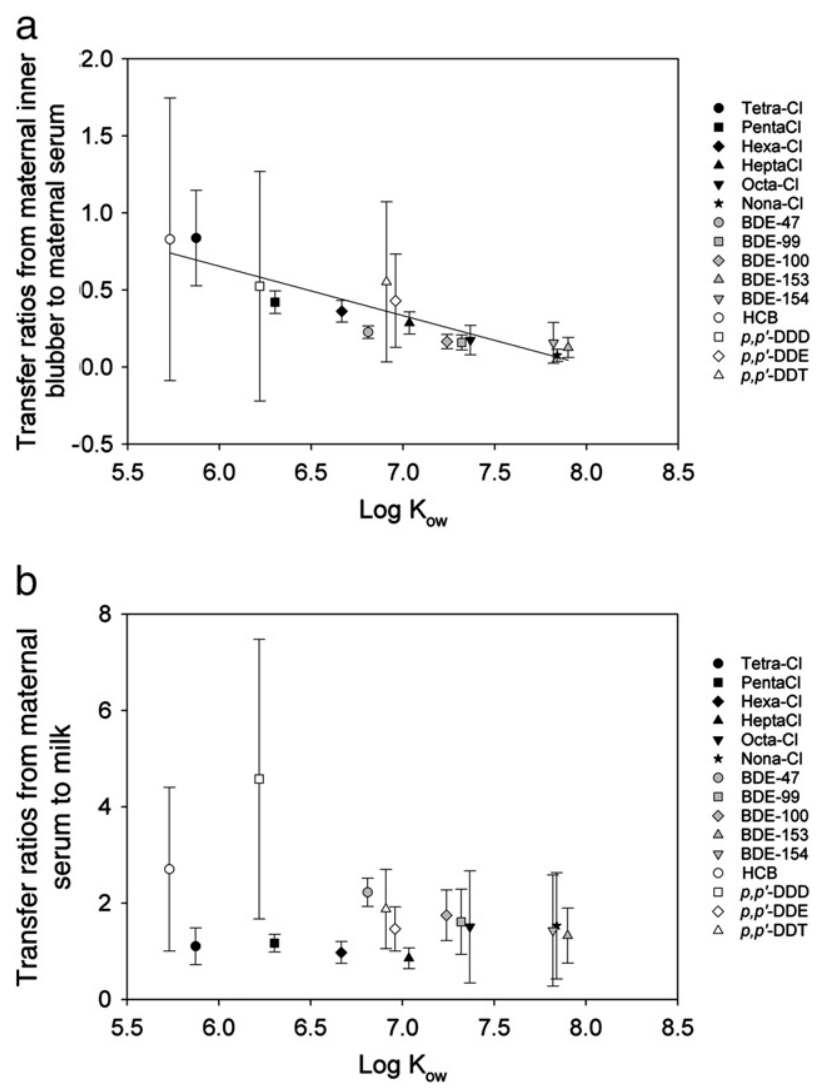

Fig. 3. Relationship between transfer ratios from maternal inner blubber to maternal serum of PCBs, PBDEs and OCPs and their respective $\log K_{o w}$ (a) and relationship between transfer ratios from maternal serum to milk of PCBs, PBDEs and OCPs and their respective $\log K_{\text {ow }}$ (b). Log $K_{\text {ow }}$ values were compiled from Hansen et al. (1999) for PCBs, Braekevelt et al. (2003) for PBDEs, De Bruijn et al. (1989) for pesticides and Yu et al. (2008) for MeO-PBDEs. Log $\mathrm{K}_{\mathrm{ow}}$ for the different PCB groups was calculated as the mean of $\log \mathrm{K}_{\mathrm{ow}}$ of each $\mathrm{PCB}$ congener present in the corresponding group (e.g. $\log \mathrm{K}_{\mathrm{ow}}$ penta-Cl corresponds to the mean of $\log \mathrm{K}_{\mathrm{ow}}$ of $\mathrm{CB}-87,95,99,101,105$, 110 and 118). principally from the inner blubber layer, while the outer part remained more stable (Strandberg et al., 2008). However, in the present study, we observed a slight but significant decrease in lipid content in the outer layer as well. Wheatley et al. (2007) observed changes in the fatty acid composition of outer blubber between early and late lactation in lactating Weddell seals (Leptonychotes weddellii). Together, these findings indicate that outer blubber may also be involved, to some extent, in the lipid dynamics during lactation in seals. The decrease in lipid content in maternal blubber layers was associated with an increase of $\Sigma$ PCBs, $\Sigma$ PBDEs and $\Sigma$ DDXs on a lipid weight basis in both layers. The increase was, however, more profound in the inner layer than in the outer layer.

Similar findings were found for PCBs in lactating and fasting seals (Debier et al., 2003b, 2006; Vanden Berghe et al., 2010) and the authors suggested a less efficient mobilisation of PCBs from blubber than triacylglycerols, resulting in increasing concentrations in the reduced blubber layer. It is also possible that POPs are mobilised from maternal blubber into the bloodstream together with the lipids but due to their higher affinity for the remaining blubber triacylglycerols, some POPs may be reabsorbed by the blubber, while the rest may end up into the milk. In both cases, the result is an accumulation of POPs in blubber over the course of lactation, especially the inner part (levels more than 2 times higher at late lactation compared to early lactation). In addition, a mobilisation of POPs from other tissues such as the liver, muscles or kidneys may also occur during lactation, as observed for lactating rodents (Lee et al., 2009; Poul, 1991; Vodicnik and Lech, 1980). Once into the blood circulation, one part of these compounds may be absorbed by the blubber because of the larger amount of fat present in this tissue and their higher affinity for triacylglycerols, as mentioned previously.

For most POPs, our LMMs showed a significant effect of total concentrations found in the "previous" compartment of transfer on total concentrations encountered in the "following" compartment of transfer (outer blubber $\rightarrow$ inner blubber $\rightarrow$ serum $\rightarrow$ milk $\quad$ - see Section 2.4). These findings suggest that the contamination of milk depends in great part on the mobilisation of POPs from maternal blubber, transport into the bloodstream and uptake by the mammary gland. Although not always statistically significant, total concentrations of most POPs tended to be also higher in maternal serum and milk at late lactation. When results were expressed per unit of wet weight, concentrations of PCBs, PBDEs and DDXs were significantly higher at late lactation as compared to early lactation in milk (results not shown). Similar dynamics have already been observed in maternal serum and milk for PCBs in lactating grey seals from the same colony (Debier et al., 2003b; Vanden Berghe et al., 2010). The authors suggested that the greatest part of the PCB mobilisation from maternal blubber may occur at late lactation, resulting in increasing PCB levels in maternal serum and then in milk at that same period. In addition, as suggested earlier, POPs from other tissues than blubber may also be released into the blood, contributing to the increase of concentrations observed in maternal serum and milk.

The important daily ingestion of contaminated milk, with higher POP concentrations at late lactation, leads to the accumulation of POPs in the suckling pups, as shown by the higher POP concentrations in their serum at late lactation, despite the important body dilution due to a rapid accumulation of weight.

\subsubsection{Variations in profiles}

Profiles also changed over the course of lactation, which was especially apparent for PCBs and PBDEs. In blubber, the proportions of lower chlorinated PCBs (tetra- to hexa-CBs) and the lower brominated BDE-47 tended to decrease at late lactation, while the percentages of higher halogenated congeners remained stable or increased. It thus appears that the mobilisation of POPs from maternal blubber is a selective phenomenon. Indeed, the transfer ratios of PCBs and PBDEs from maternal inner blubber to maternal serum decreased 
with the number of chlorine and bromine atoms and a significant inverse relationship was observed between the transfer ratios of PCBs, PBDEs and OCPs and their respective $\log \mathrm{K}_{\mathrm{ow}}$ values. These results indicate that compounds with a high $\log \mathrm{K}_{\mathrm{ow}}$ and thus with a high lipophilicity are less easily transferred into the bloodstream, which is characterised by more polar lipids than blubber. HCB, which has the lowest $\log \mathrm{K}_{\mathrm{ow}}$ value, has a comparable transfer ratio to tetra-CBs and both compounds appear thus to be more efficiently transferred into blood. Such a selective transfer from blubber into blood has already been reported for PCBs and OCPs in seals (Debier et al., 2003a; Sørmo et al., 2003), but the present study is, to our knowledge, the first to highlight a similar pattern for PBDEs.

In maternal serum, profiles also changed towards lower proportions of tetra- to hepta-CBs and BDE-47 and higher proportions of octa- to deca-CBs and BDE-99 to BDE-154 at late lactation. Several hypotheses may explain these findings. A higher mobilisation of highly halogenated compounds from maternal blubber may start at late lactation, as already suggested by Debier et al. (2003a). Such dynamics may be linked, at least in part, to a selective mobilisation of fatty acids according to their physico-chemical properties, as detailed in Debier et al. (2006) and Vanden Berghe et al. (2010). In addition, a biological barrier towards some POPs may exist at the mammary gland, resulting in the accumulation of higher halogenated PCBs and PBDEs in maternal serum at late lactation as suggested in Debier et al. (2003a) and Sørmo et al. (2003). The percentages of higher halogenated compounds increased at late lactation in maternal serum, while they decreased or remained stable in milk. These opposite trends between both tissues for higher halogenated congeners support the hypothesis of the existence of a physiological barrier at the mammary gland for those compounds. However, contrary to what was observed for the transfer from maternal inner blubber to maternal serum, no clear relationship was found between POP transfer ratios from maternal serum to milk and their degree of lipophilicity $\left(\log \mathrm{K}_{\mathrm{ow}}\right.$ ). In addition, highly halogenated compounds had transfer ratios from maternal serum to milk $>1$, suggesting an efficient transfer of those compounds from maternal serum to the milk at the end of the lactating period.

In pup serum, the profiles for most investigated POPs remained relatively stable between early and late lactation.

\subsection{Maternal transfer of $\mathrm{HO}-\mathrm{PCBS}$}

Total HO-PCB concentrations increased significantly at late lactation in maternal serum. This result suggests an increasing biotransformation of PCBs over the course of lactation. All potential precursors of the HOPCBs encountered in lactating females (see Table S5 in the supplementary information) were indeed present in their serum in significant amounts (Table 2). However, this may also be explained by a mobilisation from other tissues such as blubber and liver, which are known to contain HOPCBs (Gebbink et al., 2008), as suggested for the parent compounds. Although rodent studies reported generally a down-regulation of CYP expression during lactation (Borlakoglu et al., 1993; He et al., 2005), it is important to keep in mind that in our case, grey seal females fast throughout the entire lactation period. This particular case may also modulate the expression and activity of CYPs. Such an observation has already been described in Arctic charr (Salvelinus alpinus), a fish species that undertakes prolonged fasting periods (Vijayan et al., 2006). CYP1A protein expression was significantly enhanced in the liver of fasting fish that were experimentally treated by PCBs, indicating that an extended fasting may increase the impact of PCBs on the liver metabolism in charr. As grey seal females also undertake an important fasting during lactation, a similar phenomenon may occur in these animals.

Contrary to their parent compounds, hydroxylated metabolites are preferentially retained in the blood due to their affinity for plasma proteins (Letcher et al., 2000). This is probably why only 4-HO-CB107 was detected in milk at very low concentrations compared to those found in maternal and pup sera. Studies on human milk also indicated that only a low amount of HO-PCBs is transferred through lactation (Fangstrom et al., 2005; Guvenius et al., 2003). Interestingly, in addition to 4-HO-CB-107 which was found in all pup serum samples, most of the metabolites detected in maternal serum were also found in pup serum. Similar findings were observed by Gabrielsen et al. (2011) in hooded seal mother-pup pairs. The presence of HO-PCBs in pup serum may have different origins. HO-PCBs were transferred to the foetus during gestation as reported for humans and rodents (Guvenius et al., 2003; Meerts et al., 2002). Nevertheless, we also observed that concentrations of $\mathrm{LHO}-\mathrm{PCB}$ as well as most detected HO-metabolites increased significantly at late lactation in pup serum, most probably resulting from two possibilities. First, since low hepatic CYP activities have been demonstrated in suckling harp seal and hooded seal pups sampled once during lactation (Wolkers et al., 2002, 2009), it is possible that pups accumulate these HO-PCBs via endogenous biotransformation of PCBs. Indeed, all possible precursors of the HOPCBs encountered in pup serum in the present study (see Table S5) were present in significant amounts (Table 2). It has been shown that CYP activities in humans are reduced during the neonatal period but increase with advancing age (Milsap and Jusko, 1994). Phase I reactions (e.g., hydroxylation) develop quickly and reach adult capacities at the age of 6 months (Milsap and Jusko, 1994). Increasing CYP activities may thus explain the increasing HO-PCB levels observed in the serum of our grey seal pups. This hypothesis is supported by the findings of Gabrielsen et al. (2011) who reported positive correlations between HO-PCB levels and the age of hooded seal pups. The second explanation for the increasing HO-PCB levels in pup serum may result from a transfer through the milk. Indeed, although only 4-HO-CB-107 could be detected in milk, the other metabolites found in pup serum may be present in trace amounts in milk, allowing pups to bioaccumulate these metabolites in their blood through lactation. However, the LMMs did not show any effect of the concentrations of HO-PCBs in maternal serum on the concentrations of HO-PCBs in milk. Similarly, there was no effect of HO-PCBs in milk on HO-PCBs in pup serum, which suggests that the transfer of HO-PCBs through the milk is probably not the major route.

\subsection{Maternal transfer of the naturally-produced MeO-PBDEs}

This is the first study reporting on the maternal transfer of $\mathrm{MeO}$ PBDEs in marine mammals during lactation. Levels of MeO-PBDEs increased at late lactation in maternal inner blubber and milk. MeOPBDEs are highly lipophilic compounds $\left(\log \mathrm{K}_{\mathrm{ow}}=6.91\right.$ and 7.17 for 2'-MeO-BDE-68 and 6-MeO-BDE-47, respectively) (Yu et al., 2008) and tend to accumulate preferentially in blubber. Indeed, only limited amounts of MeO-PBDEs seemed to be transferred through milk as reflected by the very low levels found in maternal serum and milk compared to maternal blubber. This may result either from a higher retention of those compounds by the blubber or from a mobilisation combined to a direct reabsorption by this tissue, as explained in Section 4.2. The LMMs did not show any effect of the concentrations of MeO-PBDEs in maternal inner blubber on the concentrations of MeO-PBDEs in maternal serum. Similarly, there was no effect of the concentrations of MeO-PBDEs in maternal serum on the concentrations of MeO-PBDEs in milk, supporting that the transfer of MeO-PBDEs from maternal blubber to milk was limited. Interestingly, none of the $2 \mathrm{MeO}-$ PBDEs could be found in pup serum. Contrary to their mothers that were exposed to MeO-PBDEs via their diet prior to lactation, pups are exposed to relatively low levels of MeO-PBDEs through milk. It is possible that these metabolites are present in pup serum but at concentrations below the limit of quantification. Another hypothesis could be that pups are not efficient at absorbing these molecules. However, Covaci et al. (2010) detected significant levels of MeOPBDEs in harbour seal pup liver and blubber, indicating an efficient absorption and storage of these compounds by seal pups. Due to their 
high lipophilic properties, MeO-PBDEs may be rapidly deposed in pup blubber following intestinal absorption, as suggested for adult females, leading to low or undetectable levels in pup serum.

\section{Conclusions}

This study advances the knowledge on the transfer of POPs during lactation in grey seals, especially concerning PBDEs, HO-PCBs and MeO-PBDEs. For the first time, we showed that PBDEs were selectively transferred from maternal blubber into serum of lactating grey seals. We have also observed a very low lactational transfer of HO-PCBs in grey seals, as previously reported for humans and laboratory animals. In addition, HO-PCB metabolites were found to accumulate in pups, suggesting, among other things, that the biotransformation rate of PCBs increased with the advancing age of the suckling pup. Finally, only low levels of MeO-PBDEs were found in maternal tissues and none of the congeners could be detected in pup serum, suggesting that the presence of organisms producing these compounds is low in the UK marine environment.

\section{Acknowledgements}

The authors thank Simon Moss (SMRU) and the 2008 field teams. Marie Vanden Berghe is financially supported by the FRIA. Liesbeth Weijs and Adrian Covaci are financially supported by the FWOFlanders. Krishna Das is a FRS-FNRS Research Associate. The analytical part of the study was conducted thanks to the financial support of the FNRS (FRFC project), Belgium. The field work in the UK was supported by the NERC funding.

\section{Appendix A. Supplementary data}

Supplementary data to this article can be found online at http:// dx.doi.org/10.1016/j.envint.2012.04.011.

\section{References}

Borlakoglu JT, Scott A, Henderson CJ, Wolf CR. Alterations in rat hepatic drug metabolism during pregnancy and lactation. Biochem Pharmacol 1993;46:29-36.

Braekevelt E, Tittlemier SA, Tomy GT. Direct measurement of octanol-water partition coefficients of some environmentally relevant brominated diphenyl ether congeners. Chemosphere 2003;51:563-7.

Covaci A, Losada S, Roosens L, Vetter W, Santos FJ, Neels H, et al. Anthropogenic and naturally occurring organobrominated compounds in two deep-sea fish species from the Mediterranean Sea. Environ Sci Technol 2008;42:8654-60.

Covaci A, Weijs L, Berger ML, Neels H, Shaw SD. MeO-PBDEs, HO-PBDEs and HO-PBCs in liver samples of harbor seals from the northwest atlantic. Organohalogen Compd 2010;72:685-8.

De Bruijn J, Busser F, Seinen W, Hermens J. Determination of octanol/water partition coefficients for hydrophobic organic chemicals with the "slow-stirring" method. Environ Toxicol Chem 1989;8:499-512.

Debier C, Pomeroy PP, Baret PV, Mignolet E, Larondelle Y. Vitamin E status and the dynamics of its transfer between mother and pup during lactation in grey seals (Halichoerus grypus). Can J Zool 2002;80:727-37.

Debier C, Pomeroy PP, Dupont C, Joiris C, Comblin V, Boulengé EL, et al. Dynamics of $\mathrm{PCB}$ transfer from mother to pup during lactation in UK grey seals (Halichoerus grypus): differences in PCB profile between compartments of transfer and changes during the lactation period. Mar Ecol Prog Ser 2003a;247:249-56.

Debier C, Pomeroy PP, Dupont C, Joiris C, Comblin V, Boulengé EL, et al. Quantitative dynamics of PCB transfer from mother to pup during lactation in UK grey seals (Halichoerus grypus). Mar Ecol Prog Ser 2003b;247:237-48.

Debier C, Chalon C, Le Boeuf BJ, de Tillesse T, Larondelle Y, Thomé J-P. Mobilization of PCBs from blubber to blood in northern elephant seals (Mirounga angustirostris) during the post-weaning fast. Aquat Toxicol 2006;80:149-57.

Dirtu AC, Jaspers VLB, Cernat R, Neels H, Covaci A. Distribution of PCBs, their hydroxylated metabolites, and other phenolic contaminants in human serum from two European countries. Environ Sci Technol 2010;44:2876-83.

Espeland O, Kleivane L, Haugen S, Skaare JU. Organochlorines in mother and pup pairs in two Arctic seal species: harp seal (Phoca groenlandica) and hooded seal (Cystophora cristata). Mar Environ Res 1997;44:315-30.

Fangstrom B, Strid A, Grandjean P, Weihe P, Bergman A. A retrospective study of PBDEs and PCBs in human milk from the Faroe Islands. Environ Health Global Access Sci Source $2005 ; 4: 12$.
Frouin Hls, Lebeuf M, Hammill M, Sjare B, Fournier M. PBDEs in serum and blubber of harbor, grey and harp seal pups from Eastern Canada. Chemosphere 2011;82:663-9.

Frouin H, Lebeuf M, Hammill M, Fournier M. Transfer of PBDEs and chlorinated POPs from mother to pup during lactation in harp seals Phoca groenlandica. Sci Total Environ 2012. http://dx.doi.org/10.1016/j.scitotenv.2011.11.084.

Gabrielsen KMl, Villanger GD, Lie E, Karimi M, Lydersen C, Kovacs KM, et al. Levels and patterns of hydroxylated polychlorinated biphenyls ( $\mathrm{OH}-\mathrm{PCBs})$ and their associations with thyroid hormones in hooded seal (Cystophora cristata) mother-pup pairs. Aquat Toxicol 2011;105:482-91.

Gebbink WA, Sonne C, Dietz R, Kirkegaard M, Riget FF, Born EW, et al. Tissue-specific congener composition of organohalogen and metabolite contaminants in East Greenland polar bears (Ursus maritimus). Environ Pollut 2008;152:621-9.

Guvenius DM, Aronsson A, Ekman-Ordeberg G, Bergman Ãk, Norén K. Human prenatal and postnatal exposure to polybrominated diphenyl ethers, polychlorinated biphenyls, polychlorobiphenylols, and pentachlorophenol. Environ Health Perspect 2003;111: 1235-41.

Hall AJ, Kalantzi OI, Thomas GO. Polybrominated diphenyl ethers (PBDEs) in grey seals during their first year of life - are they thyroid hormone endocrine disrupters? Environ Pollut 2003;126:29-37.

Hansen BG, Paya-Perez AB, Rahman M, Larsen BR. QSARs for KOW and KOC of PCB congeners: a critical examination of data, assumptions and statistical approaches. Chemosphere 1999;39:2209-28.

He XJ, Ejiri N, Nakayama H, Doi K. Changes in cytochrome p450 isozymes (cyps) protein levels during lactation in rat liver. Exp Mol Pathol 2005;79:224-8.

Ikonomou MG, Addison RF. Polybrominated diphenyl ethers (PBDEs) in seal populations from eastern and western Canada: an assessment of the processes and factors controlling PBDE distribution in seals. Mar Environ Res 2008;66:225-30.

Iverson SJ, Bowen WD, Boness DJ, Oftedal OT. The effect of maternal size and milk energy output on pup growth in grey seals (Halichoerus grypus). Physiol Zool 1993;66:61-88.

Law RJ, Bersuder P, Barry J, Deaville R, Reid RJ, Jepson PD. Chlorobiphenyls in the blubber of harbour porpoises (Phocoena phocoena) from the UK: levels and trends 1991-2005. Mar Pollut Bull 2010;60:470-3.

Lee SK, Hamer D, Bedwell CL, Lohitnavy M, Yang RSH. Effect of PCBs on the lactational transfer of methyl mercury in mice: PBPK modeling. Environ Toxicol Pharmacol 2009;27:75-83.

Letcher R, Klasson-Wehler E, Bergman A. Methyl sulfone and hydroxylated metabolites of polychlorinated biphenyls. The handbook of environmental chemistryBerlin/Heidelberg: Springer; 2000. p. 315-59.

Løken K, Lie E, Sørmo EG, Jenssen BM, kaare JU. How important are the hydroxylated PCB metabolites (OH-PCB) in harbour seals (Phoca vitulina). Organohalogen Compd 2008;70:825-8.

Malmvärn A, Marsh G, Kautsky L, Athanasiadou M, Bergman Å, Asplund L Hydroxylated and methoxylated brominated diphenyl ethers in the red algae ceramium tenuicorne and blue mussels from the baltic sea. Environ Sci Technol 2005;39:2990-7.

Meerts IATM, van Zanden JJ, Luijks EAC, van Leeuwen-Bol I, Marsh Gr, Jakobsson E, et al Potent competitive interactions of some brominated flame retardants and related compounds with human transthyretin in vitro. Toxicol Sci 2000;56:95-104.

Meerts IATM, Assink Y, Cenijn PH, van den Berg JHJ, Weijers BM, Bergman Ãk, et al. Placental transfer of a hydroxylated polychlorinated biphenyl and effects on fetal and maternal thyroid hormone homeostasis in the rat. Toxicol Sci 2002;68:361-71.

Milsap RL, Jusko WJ. Pharmacokinetics in the infant. Environ Health Perspect 1994;102:107-10.

Miranda Filho KC, Metcalfe CD, Metcalfe TL, Muelbert MMC, Robaldo RB, Martinez PE, et al. Lactational transfer of PCBs and chlorinated pesticides in pups of southern elephant seals (Mirounga leonina) from Antarctica. Chemosphere 2009;75:610-6.

Mos L, Tabuchi M, Dangerfield N, Jeffries SJ, Koop BF, Ross PS. Contaminant-associated disruption of vitamin A and its receptor (retinoic acid receptor $\alpha$ ) in free-ranging harbour seals (Phoca vitulina). Aquat Toxicol 2007;81:319-28.

Newsome WH, Davies D. Determination of PCB metabolites in Canadian human milk Chemosphere 1996;33:559-65.

Nyman M, Raunio H, Taavitsainen Pi, Pelkonen O. Characterization of xenobiotic-metabolizing cytochrome P450 (CYP) forms in ringed and grey seals from the Baltic Sea and reference sites. Comp Biochem Physiol C Toxicol Pharmacol 2001;128:99-112.

Pomeroy P, Green N, Hall A, Walton M, Jones K, Harwood J. Congener-specific exposure of grey seal (Halichoerus grypus) pups to chlorinated biphenyls during lactation. Can J Fish Aquat Sci 1996;53:1526-34.

Pomeroy PP, Fedak MA, Rothery P, Anderson S. Consequences of maternal size for reproductive expenditure and pupping success of grey seals at North Rona Scotland. J Anim Ecol 1999;68:235-53.

Poul JM. Time course reversibility of liver and blood changes induced in weanling rats after polychlorinated biphenyl exposure during lactation. Arch Environ Contam Toxicol 1991;21:528-35.

Routti H, Letcher RJ, Chu S, van Bavel B, Gabrielsen GW. Polybrominated diphenyl ethers and their hydroxylated analogues in ringed seals (Phoca hispida) from Svalbard and the Baltic Sea. Environ Sci Technol 2009;43:3494-9.

Simms W, Jeffries S, Ikonomou M, Ross PS. Contaminant-related disruption of vitamin a dynamics in free-ranging harbor seal (Phoca vitulina) pups from British Columbia, Canada, and Washington State, USA. Environ Toxicol Chem 2000;19:2844-9.

Sørmo EG. Immunotoxicity of polychlorinated biphenyls (PCB) in free-ranging gray seal pups with special emphasis on dioxin-like congeners. J Toxicol Environ Health A 2009;72:266-76.

Sørmo EG, Skaare JU, Lydersen C, Kovacs KM, Hammill MO, Jenssen BM. Partitioning of persistent organic pollutants in grey seal (Halichoerus grypus) mother-pup pairs. Sci Total Environ 2003;302:145-55. 
Strandberg U, Käkelä A, Lydersen C, Kovacs KM, Grahl-Nielsen O, Hyvärinen H, et al. Stratification, composition, and function of marine mammal blubber: the ecology of fatty acids in marine mammals. Physiol Biochem Zool 2008;81:473-85.

Teuten EL, Xu L, Reddy CM. Two abundant bioaccumulated halogenated compounds are natural products. Science 2005;307:917-20.

Vanden Berghe M, Mat A, Arriola A, Polain S, Stekke V, Thomé J-P, et al. Relationships between vitamin A and PCBs in grey seal mothers and pups during lactation. Environ Pollut 2010;158:1570-5.

Vetter W, Stoll E, Garson MJ, Fahey SJ, Gaus C, Müller JF. Sponge halogenated natural products found at parts-per-million levels in marine mammals. Environ Toxicol Chem 2002;21:2014-9.

Vijayan MM, Aluru N, Maule AG, Jørgensen EH. Fasting augments PCB impact on liver metabolism in anadromous arctic char. Toxicol Sci 2006;91:431-9.

Vodicnik MJ, Lech JJ. The transfer of 2,4,5,2',4',5'-hexachlorobiphenyl to fetuses and nursing offspring : I. Disposition in pregnant and lactating mice and accumulation in young. Toxicol Appl Pharmacol 1980;54:293-300.

Wan Y, Wiseman S, Chang H, Zhang X, Jones PD, Hecker M, et al. Origin of hydroxylated brominated diphenyl ethers: natural compounds or man-made flame retardants? Environ Sci Technol 2009;43:7536-42.

Weijs L, Losada S, Das K, Roosens L, Reijnders PJH, Santos JF, et al. Biomagnification of naturally-produced methoxylated polybrominated diphenyl ethers (MeO-PBDEs) in harbour seals and harbour porpoises from the Southern North Sea. Environ Int 2009a; 35:893-9.

Weijs L, Dirtu AC, Das K, Gheorghe A, Reijnders PJH, Neels H, et al. Inter-species differences for polychlorinated biphenyls and polybrominated diphenyl ethers in marine top predators from the Southern North Sea: part 1. Accumulation patterns in harbour seals and harbour porpoises. Environ Pollut 2009b;157:437-44.

Weijs L, Das K, Siebert U, van Elk N, Jauniaux T, Neels H, et al. Concentrations of chlorinated and brominated contaminants and their metabolites in serum of harbour seals and harbour porpoises. Environ Int 2009c;35:842-50.
Weijs L, Das K, Neels H, Blust R, Covaci A. Occurrence of anthropogenic and naturallyproduced organohalogenated compounds in tissues of Black Sea harbour porpoises. Mar Pollut Bull 2010;60:725-31.

Wheatley KE, Nichols PD, Hindell MA, Harcourt RG, Bradshaw CJA. Temporal variation in the vertical stratification of blubber fatty acids alters diet predictions for lactating Weddell seals. J Exp Mar Biol Ecol 2007;352:103-13.

Wheatley KE, Nichols PD, Hindell MA, Harcourt RG, Bradshaw CJA. Differential mobilization of blubber fatty acids in lactating weddell seals: evidence for selective use. Physiol Biochem Zool 2008;81:651-62.

Wiseman SB, Wan Y, Chang H, Zhang X, Hecker M, Jones PD, et al. Polybrominated diphenyl ethers and their hydroxylated/methoxylated analogs: environmental sources, metabolic relationships, and relative toxicities. Mar Pollut Bull 2011;63: 179-88.

Wolkers H, Burkow IC, Hammill MO, Lydersen C, Witkamp RF. Transfer of polychlorinated biphenyls and chlorinated pesticides from mother to pup in relation to cytochrome P450 enzyme activities in harp seals (Phoca groenlandica) from the Gulf of St. Lawrence, Canada. Environ Toxicol Chem 2002;21:94-101.

Wolkers H, Hammill MO, van Bavel B. Tissue-specific accumulation and lactational transfer of polychlorinated biphenyls, chlorinated pesticides, and brominated flame retardants in hooded seals (Cystophora cristata) from the Gulf of St. Lawrence: applications for monitoring. Environ Pollut 2006;142:476-86.

Wolkers H, Boily F, Fink-Gremmels J, van Bavel B, Hammill M, Primicerio R. Tissuespecific contaminant accumulation and associated effects on hepatic serum analytes and cytochrome p450 enzyme activities in hooded seals (Cystophora cristata) from the Gulf of St. Lawrence. Arch Environ Contam Toxicol 2009;56: 360-70.

Yu Y, Yang W, Gao Z, Lam MHW, Liu X, Wang L, et al. RP-HPLC measurement and quantitative structure-property relationship analysis of the n-octanol-water partitioning coefficients of selected metabolites of polybrominated diphenyl ethers. Environ Chem 2008:5:332-9. 